\title{
2. Tropical Montane Cloud Forests: Conservation Status and Management Issues
}

\author{
Charles Doumenge, Don Gilmour, \\ Manuel Ruíz Pérez, and Jill Blockhus \\ With the collaboration of the World Conservation Monitoring Centre; \\ Cambridge, UK, and Alain Gioda, ORSTOM, Montpellier, France
}

In the humid tropics, montane cloud forests are found between 500 and 3,500 $\mathrm{m}$ altitude (LaBastille and Pool 1978; Unesco 1981; Sosa 1987; Stadtmüller 1987; Fao 1992) with major occurrence between 1,200 and $2,500 \mathrm{~m}$ (Stadtmüller 1987). They may occur within the montane and submontane floristic zones.

Within the humid tropical zone, one can observe some vegetation gradients with increasing altitude: diminishing tree height, simplified stratification, smaller leaf size, more open understory, some floristic changes, and more epiphytes, mosses, and lichens (Whitmore 1975; Unesco 1981; White 1983; Jacobs 1988). Tropical montane forests are usually of low stature (White 1983; Letouzey 1985; Sayer, Harcourt, and Collins 1992) whereas submontane forests have greater height (20-30 m vs. $15-25 \mathrm{~m})$, are richer in species, with more vascular epiphytes, and incorporate species from low and mid-altitude forests (Letouzey 1985; Thomas and Achoundong 1991).

In this paper, we will refer to tropical montane cloud forests (TMCF) in a topographic sense, as cloud forests lying on wetter mountainsides, ridges and saddles, whether in montane or submontane floristic zones. They can be defined as tropical montane or submontane forests characterized by persistent clouds or fogs, sometimes with small trees, often with abundant mosses, ferns, lichens, or flowering plants in trees and on soil surface. 


\section{Global Distribution}

In Table 1 and Figures 1-3, we have summarized available information on the geographical distribution and overlap extent of montane and submontane forests. According to recent FAO estimates (Table 1), montane and submontane forests comprise more than 11 percent of the total tropical forests. According to Persson's (1974) estimates, cloud forests occur in a portion of this area and cover about 50 million ha, or one-fourth of the montane and submontane forests. These estimates should be considered as border figures because of a lack of precise data on the extent and distribution of TMCF within these broader montane and submontane forest categories. Cloud forests occur on humid mountain slopes where topo-climate conditions are favorable to the occurrence of ground-level clouds during a considerable period of the year. They occur more frequently in tropical America and Southeast Asia than in tropical Africa (Stadtmüller 1987). The reason for the difference is that there is a wider distribution of mountain ranges, subject to oceanic influences, in America and Asia than in Africa.

Apart from this general distribution, TMCF does appear as micro-occurrences, in locations where there is a cooler climate and a stronger influence of mists and clouds than might normally be expected. In Africa, some of these cloud forest micro-occurrences include isolated low elevation mountains exposed to wind and clouds such as the Belinga mountains of Gabon (800-900 m) and other topographical situations where low elevation passes or peaks are exposed to oceanic influences (e.g., in Congo, the Mayombe mountains, 500-700 m, [Cusset 1989; Dowsett-Lemaire 1991]); the Angola Highlands, where there is an extension of dense forests from southern Zaire, which also include important occurrences of cloud forests (White 1983; Stuart, Adams, and Jenkins 1990; Thomas and Achoundong 1991).

Table 1. Tropical montane and submontane forest cover and deforestation rate compared to the entire tropics

\begin{tabular}{|c|c|c|c|c|c|}
\hline \multirow{2}{*}{$\begin{array}{l}4 \\
4 \\
4\end{array}$} & \multirow[b]{2}{*}{$\begin{array}{l}\text { Land Area } \\
\text { (million ha) }\end{array}$} & \multicolumn{2}{|c|}{ Forest Cover 1990} & \multicolumn{2}{|c|}{$\begin{array}{c}\text { Annual Deforestation } \\
1981-90\end{array}$} \\
\hline & & $\begin{array}{c}\text { Total } \\
\text { (million ha) }\end{array}$ & $\begin{array}{l}\text { Land Area } \\
\qquad(\%)\end{array}$ & $\begin{array}{c}\text { Total } \\
\text { (million ha) }\end{array}$ & $\begin{array}{l}\text { \% per } \\
\text { Year }\end{array}$ \\
\hline Total & $4,778.3$ & $1,756.3$ & 37 & 15.4 & 0.8 \\
\hline Hills and mountains & 700.9 & 204.3 & 29 & 2.5 & 1.1 \\
\hline
\end{tabular}

Source: FAO 1993. 


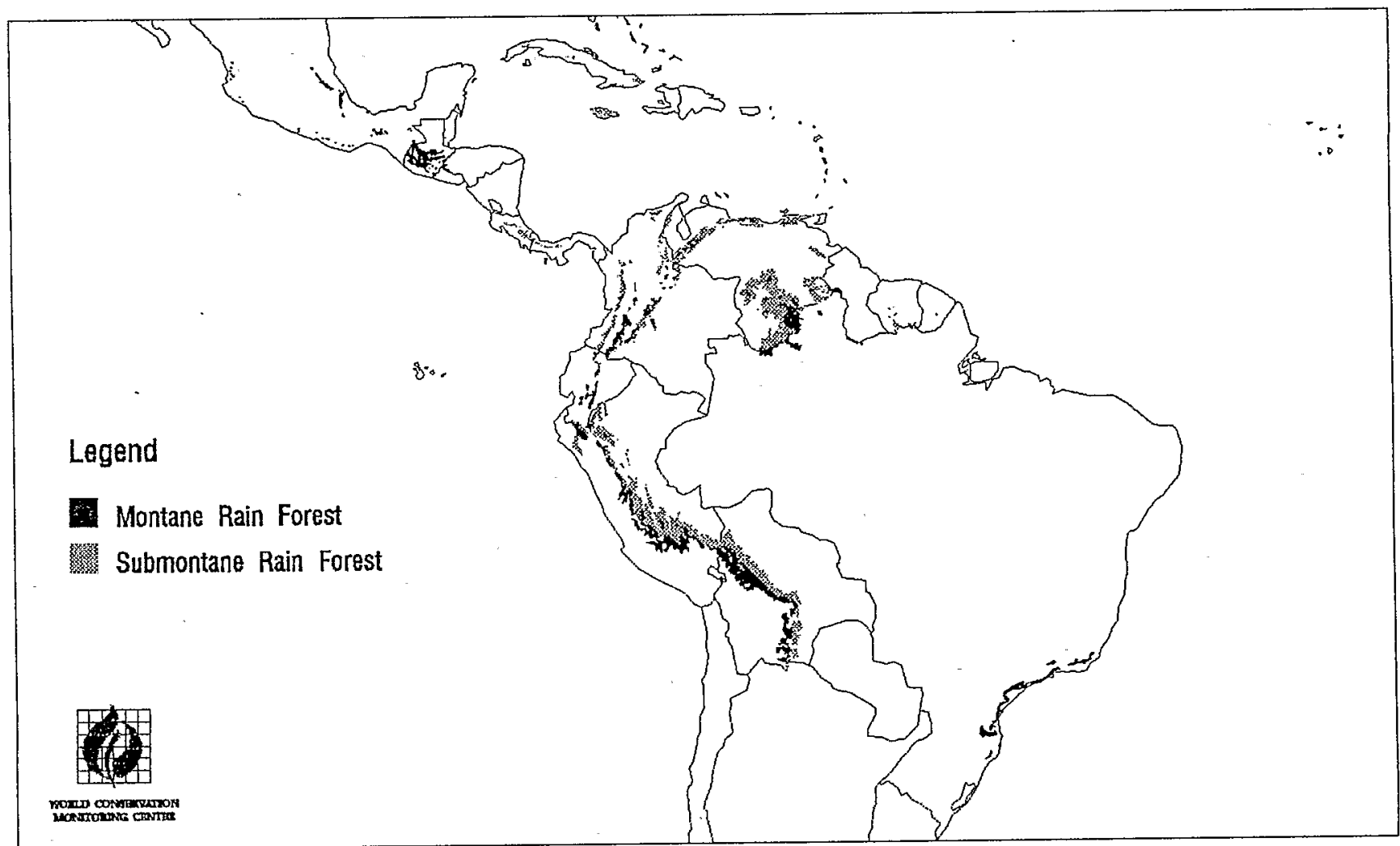

Figure 1. Distribution of tropical montane and submontane forests in Central and South America. Data are incomplete for the forest cover of Mexico, the Caribbean, and most of Central America and the southern countries of South America. (Source: World Conservation Monitoring Centre.) 


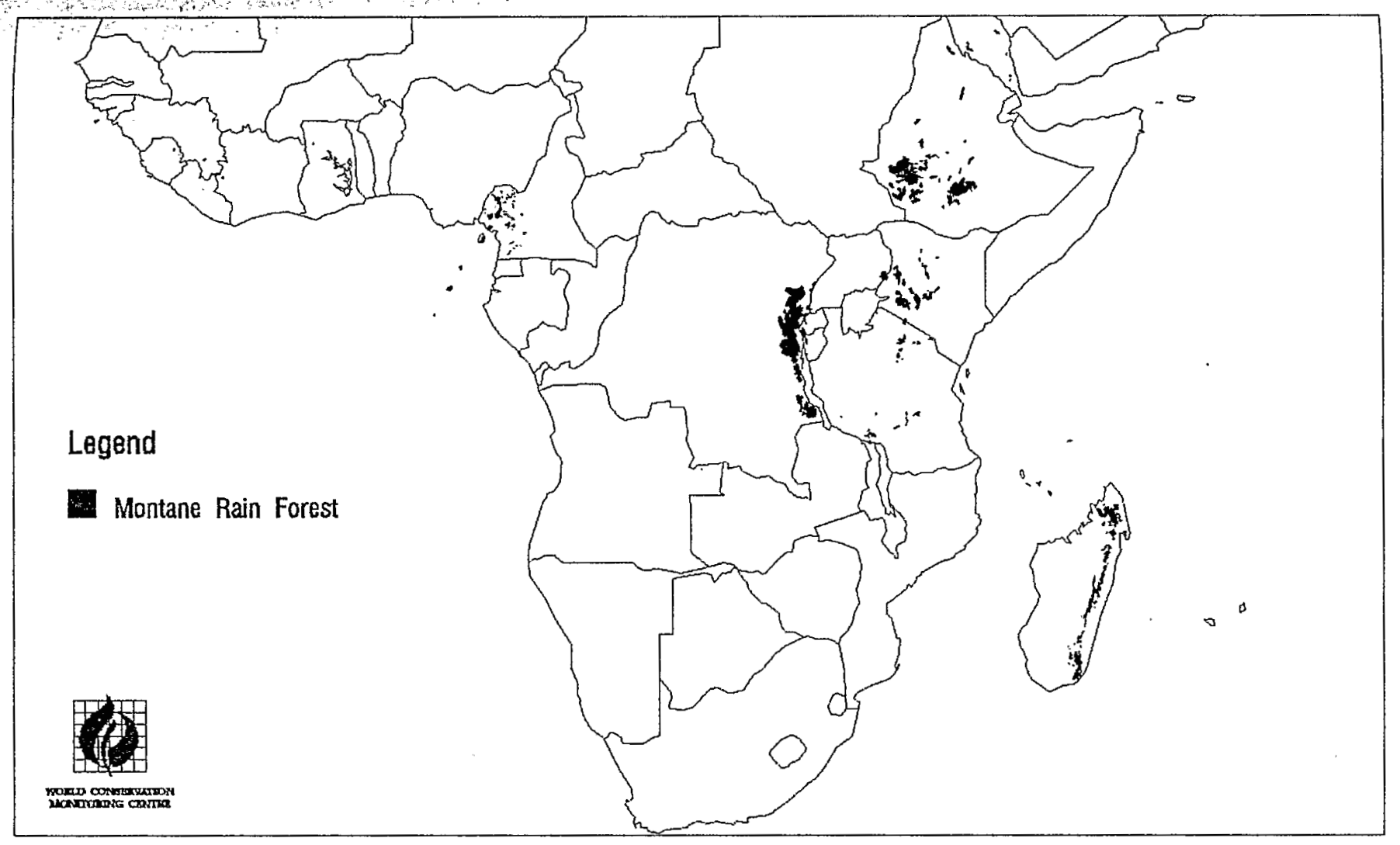






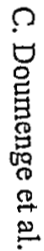

Figure 3. Distribution of tropical montane rain and monsoon forest in South and Southeast Asia and the Pacific. (Source: World Conservation Monitoring Centre.) 


\section{Values}

Tropical montane cloud forests exhibit many values related to the uniqueness of these ecosystems, in terms of their diversity and endemism, and the functions they provide. These values encompass:

- Watershed function, including a role in the capture and transport of water and protection of soils against erosion (LaBastille and Pool 1978). Evidence suggests that cloud forests perform a watershed function that is somewhat different from that performed by noncloud forests. This difference relates to the presence of the cloud itself and the occurrence of occult precipitation. The tree crowns act to intercept wind-driven cloud moisture on leaves and branches that drips to the ground. The absolute increase in net precipitation is a result of the presence of trees. This can add to the groundwater and streamflow levels, but its precise effect on the hydrological cycle is difficult to determine. The impact will, in any case, vary from place to place depending on factors such as incidence of wind-driven clouds, density of the clouds and wind speed, size and orientation of mountains, altitude, type of vegetation, and other climatic variables (see Kerfoot 1968; Stadtmüller 1987).

This "cloud stripping" phenomenon may well double the effective rainfall received in dry seasons and increase the wet season rainfall total by about 10 percent (Vogelmann 1973; Bruijnzeel 1990). Experiments to measure the extent of occult precipitation in temperate cloud forest were carried out in the Snowy Mountains in southern Australia in woodlands close to the tree line in an area with a high incidence of wind-driven clouds (Costin and Wimbush 1961). The results indicated a significant increase in net precipitation under the canopy of scattered trees compared with locations between the canopies. This contrasts strongly with the results in noncloud forests where the opposite situation occurs. That is, in noncloud forests, tree canopies frequently intercept and evaporate 20 percent or more of the incident precipitation, and this is lost to the land component of the hydrological cycle.

It can be postulated that clearing cloud forests and replacing them with vegetation with a reduced "filtering" ability will decrease net precipitation. Indirect evidence for this comes from Sri Lanka, where large areas of the central highlands montane forests have been converted to tea estates. Longterm streamflow records have indicated a decline in water yield even though there has not been a corresponding trend of decline in rainfall (Madduma Bandara and Kurupuarachchi 1988). While correlation and causation are not always the same, it is a trend that is worth exploring further.

Vegetation elements. In Sub-Saharan Africa, Stuart, Adams, and Jenkins (1990) postulated that 80 percent of about 4,000 plant species of the Afromontane region are endemic, some of them occurring in cloud forests. In cloud forests of Central America, endemism is high, especially in 
the Caribbean islands (LaBastille and Pool 1978). Throughout the tropics, the cloud forest zone provides habitat for notable species such as Podocarpus (Unesco 1981; White 1983; Sosa 1987; Jacobs 1988; FAO 1992) and tree ferns (Cyateaceae), which are common in this foggy environment (Stadtmüller 1987). In the neotropics, Luteyn (1989) determined that species of the family Ericaceae are most common in the cloud forest zone, although they are not restricted to it. The economic values of this vegetation type range from wood (often fuelwood or construction material) to medicinal plants and food plants (Torres et al. 1992), and to touristic values.

- Fauna. Possibly the best known cloud forest mammal is the Mountain Gorilla (Gorilla g. beringei), which in addition to its intrinsic value, is an important attraction for nature tourism in some countries of Central Africa (there is a similar case in South America with the Spectacled Bear). Cloud forests are also habitats for mammals and birds that play an important role in the functioning of the ecosystem, in terms of predation-dispersion of seeds and forest dynamics. Many species are valuable to local people as bushmeat, providing them with animal protein. In tropical Africa, the centers of endemism for birds largely coincide with mountainous areas, including cloud forests (Stuart, Adams, and Jenkins 1990); in South America montane areas and foothills were refuges during dry periods in the geological past, and are currently centers of diversity and endemism (Colinvaux 1989). In Costa Rica, cloud forests are covered with epiphytes, which "provide many birds with habitat and supplies of energy and nutrients," especially in the wet season (Nadkarni 1988).

Cloud forest environments in some areas have values for alternate uses, ; particularly where the soils are of high quality (LaBastille and Pool 1978). These include general agriculture, tea or coffee estates, pastures, and wood plantations (e.g., Pinus spp., Eucalyptus spp.). $\quad$ r

\section{Human Uses and Conservation Status}

Many TMCFs suffer from human pressure, particularly in the submontane area (White 1983). However, it is difficult to assess precisely the global extent of such pressures in terms of their effects on structure and composition or disappearance of the cloud forests. A recent evaluation of tropical hill and mountain forest clearance by FAO (1993) estimated that the annual rate of deforestation was about 1.1 percent for 1981-1990 (Table 1). This is greater than the rate of deforestation for the tropical forest biome as a whole, esti.mated to be about 0.8 percent per year. LaBastille and Pool (1978) estimate that the cloud forests in Central America and the Caribbean are "probably disappearing faster than any other forest ecosystem." 
A variety of nonwood forest products is harvested from cloud forests. For example, in the mountains of Central Africa, Prunus africana is heavily exploited for the medicinal properties of its bark and is in danger of extinction (Letouzey 1985). For other products, such as shoots of the edible mountain bamboo (Arundinaria alpina) in Uganda, it is difficult to assess whether or not harvesting is at a sustainable level. In heavily populated mountainous areas, the collection of fire wood (for heating and cooking) is a major contributor to forest degradation. Fires of human origin are of importance along forest edges (Thomas and Achoundong 1991). Logging, especially in submontane areas but also at higher altitudes for species such as Podocarpus, causes substantial changes to forest structure.

Hunting has a direct impact on fauna populations and an indirect impact on forest cover, as hunters regularly burn the vegetation at forest edges (and sometimes the forest itself) for ease of access and to concentrate grazing animals in areas of young vegetation.

Significant areas of cloud forests have been converted to plantations, especially in submontane areas. InAfrica, agriculture is found as high as $2,400 \mathrm{~m}$ altitude and pastures as high as 2,000-3,000 $\mathrm{m}$ (Letouzey 1985) whereas in the Andes, agriculture has been developed as high as $3,700 \mathrm{~m}$ and pastures to well over 4,000 $\mathrm{m}$ (Morlon 1992). Tea and coffee estates are common in the montane forest zone of East Africa, and tea estates are widespread in the same zone in Sri Lanka. Cloud forests on steep slopes in South America have been converted to agriculture and pastures, resulting in severe erosion (Unesco 1981). In Costa Rica, the conversion of cloud forests into pastures, even when there is a colonization by shrub trees, has resulted in a vegetation complex with fewer epiphytes, smaller biomass, and lower diversity (Nadkarni 1988). Changes in land use, such as gold mining or iron ore extraction, can lead to locally severe land degradation.

Especially in islands or isolated forests, introduction of exotic plant and animal species has favored degradation of native ecosystems (La Reunion Island, Doumenge and Renard 1989; East Usambara Mountains, Tanzania, Hamilton and Bensted-Smith 1989).

Some cloud forests are nevertheless incorporated in the existing reserves in montane areas, but their extent and conservation status are difficult to assess because of fragmented information. Generally, areas with lesser known large species, but with numerous endemics, such as montane forests, have tended to be underrepresented in networks of protected areas (Stuart, Adams, and Jenkins 1990).

In some areas, local traditions favor conservation and sustainable use of certain forest resources. For example, in some parts of Cameroon Highlands, honey collection is an important activity for the local people and beehives are placed in trees such as Schefflera spp. Some forests or parts of forests are considered sacred by local people and are afforded protection (as occurs around Lake Oku in Cameroon). 
Despite some notable examples of local protection, in most places high population density and the consequent demand for forest products and land for alternate uses are the most important factors that influence the conservation status of cloud forests. In some countries official government policies recognize the conservation value of such forests, and attempts are made to establish protected reserves. However, in heavily populated areas, current land pressures are likely to lead to the preservation of only small forest patches within a wider agricultural landscape. This is the case in montane Central Africa, where rich volcanic soils and high population densities favor conversion to agriculture and grazing lands.

\section{Management Issues}

Some important biophysical aspects should be considered when discussing management of TMCFs and converted land: The major issues are related to the role of vegetation in the hydrological cycle, long-term supply of forest products (both plants and animals), protection of soils, and maintenance of ecological processes. However, the details of the processes involved are poorly understood, and there is a lack of basic scientific data on the nature of the linkages.

The use of forest resources is increasingly driven by the immediate benefits that arise from these uses. There is often no real management of cloud forest resources based on rational assessment of the extent of goods and services that can be provided by well-managed forests. Some studies are being conducted to evaluate the carrying capacity of the environment with respect to resource use, but these studies have been recently established and are not yet fully operational.

It is frequently perceived that a lack of awareness and knowledge among local people is at the heart of unsustainable utilization of forest resources. However, it is rare that people living close to forests, and often dependent on them for their livelihood, are not aware of the importance of the forest. A more important constraint is often associated with the inability of local populations to take effective actions because of the presence of more powerful socioeconomic structures.

One essential element of effective management is the development of appropriate institutional structures to ensure that the wishes and desires of all those who have an interest in montane cloud forests can be considered. These interest groups may include a range of people, from those who depend on the forest for livelihood support to those who have an intellectual interest in forest conservation. However, the official decision-making process is normally in the hands of urban-based government officials and politicians who have the task of integrating sectoral interests with the broader interests of the state. There can also be, as in Eastern Zaire and the Cameroon Highlands, conflicts between traditional customary regulations governing the use of natural re- 
sources and state-controlled structures and laws that tend to focus on perceived national interests.

An additional influence, which often has a major impact on the way in which forests are managed, is that of in-migration. Examples can be seen in montainous parts of the Philippines where migrants, often from ethnic backgrounds different from the local indigenous populations, create situations that make effective management difficult.

\section{Conservation and Sustainable Use: Some IUCN Experiences}

The three projects described here are used as examples to illustrate a variety of approaches that may be suitable in advancing conservation objectives in areas subject to heavy pressure on forest resources. They are being implemented in montane and submontane areas where cloud forests occur, but where they cover only part of the project area. The primary goal of the projects is to ensure the conservation of forest resources by facilitating related development activities.

\section{Mount Elgon Conservation and Development Project}

The Mount Elgon Project in Eastern Uganda (financed by the Norwegian Agency for Development Cooperation) promotes a joint program of activities between the Ministry of Environment Protection of Uganda and IUCN. The long-term goal is to ensure conservation of natural forests on Mount Elgon while assisting community development activities where this development is directly linked to the sustainable use of forest products. The first phase of the project consisted of an extensive study and planning stage, combined with some immediate conservation measures. Phase two, under way, consists of implementation of a management plan for the forest and a long-term strategy aimed at promoting the sustainable use of natural resources in the area. Demarcation of the Mount Elgon Forest Park boundaries and improvement of the infrastructure and management of the park are also part of the activities. A study has recently started to determine bamboo (Arundinaria alpina) utilization patterns in the area. The plan will involve people who depend on harvesting bamboo shoots and stems in management of the bamboo resources. The goal is to continue bamboo harvesting in a sustainable manner while conserving the bamboo forests. Similar studies are planned to determine the nature of the interactions between people and other forest resources as a prelude to developing management procedures aimed at sustainable utilization.

\section{Itombwe Mountains Project}

In the Itombwe Mountains in Eastern Zaire, IUCN works closely with a governmental body, the Zairian Institute for Conservation of Nature, and with local people and NGOs. Pressures on the forests come from extension of pas- 
tures and agriculture, gathering of wood (for fuel and construction), hunting, and, in some places, gold mining. The approach selected is a participative one, bringing external expertise to work with local people and NGOs to facilitate planning and sustainable development. This participatory rural development process has permitted local people to gather information and analyze environmental and socioeconomic problems they are facing. The socioecomomic data are processed locally, and the results will be discussed with the rural people living in the area, through workshops to be held in selected villages. This action will form the basis for future project planning.

Although this process has just started, the cooperative mechanism has reinforced local awareness and local capacity to analyze and manage natural resources. This cooperative effort is vital in countries like Zaire where internal conflicts have resulted in disintegration of the administrative capacity of the official government. Some problems experienced include the necessity to send longer support missions than may be the case in normal circumstances, and the difficulty -in continuing with the analysis phase-of mobilizing funds to execute future on-ground activities in a country with political instability.

\section{Native Andean Forests Conservation Project}

A recent preliminary analysis by Intercooperation (an NGO) and IUCN of native Andean forests in Bolivia and Ecuador drew several conclusions: (1) only small patches of native montane forests remain; (2) these forest fragments are in danger of complete elimination due to pressure from uncontrolled colonization; (3) the official management institutions are ineffective with respect to protection of remaining forest areas. This analysis led to a program aimed at conservation and sustainable use of the native Andean forests by stabilizing the pressures on these forests and reclaiming degraded areas. The activities include establishing demonstration projects, strengthening institutional capacity, analyzing the legislative system, and enhancing regional coordination and knowledge sharing. This project is financed by and will be implemented by Intercooperation and the Swiss Technical Cooperation with local organizations and communities; IUCN will provide technical support.

\section{Conclusions}

The values and services provided by TMCFs should be fully recognized and taken into account in policy statements and management decisions. Management decisions should consider (1) the necessity of exploiting products within the carrying capacity of the ecosystems; (2) the value of forests in water capture and for maintaining soil stability (particularly important in areas where soils are prone to erosion); and (3) the necessity of conserving reservoirs for genetic material. The conversion of forests to other uses should be carried out only after careful impact analysis. 
Such topics for consideration are important; however, they do not meet all the conditions necessary for sustainable use of natural resources. We have provided some details of possible approaches, with references to IUCN projects. A conclusion of these project experiences is that the major constraint to cloud forest conservation is awareness and commitment of all the participants and interest groups for the long-term conservation of these forests. It is necessary to build management processes that take into account the existing and potential conflicts to be resolved and to design a human-scale approach, which is more participative, favoring integration of concerns and cooperation (Poore 1992). Similar initiatives are being implemented around the world but should be further developed, extended, and adapted to different circumstances.

The diversity of situations implies a diversity of strategies in the field, but some basic principles that apply to managing mountain ecosystems can still be valid worldwide (see global guidelines in Dasmann and Poore 1979 and Poore 1992).

While a lack of biophysical knowledge is a constraint to understanding the nature of the hydrological and ecological processes operating in TMCFs, the major need is a conceptual framework within which to address the conservation needs of cloud forests globally, regionally, and nationally. We hope that the task of providing such a framework will be undertaken. Among points that need consideration are:

\section{Globally}

- listing of the unique features and values of TMCF, including a typology;

- evaluation of extent and distribution of cloud forests, and assessment of their conservation status;

- identification of the major threats to their conservation and of sustainable practices;

- definition of a global policy on cloud forests including prioritization of those areas where immediate conservation action is required.

\section{Regionally}

- identification of the transfrontier cloud forests that deserve coordinated actions between neighboring countries;

- establishment of cooperation processes to manage sustainably transfrontier cloud forests, and design of regional policies.

\section{Nationally}

- detailed mapping of cloud forest areas and assessment of their conserva-

.. tion value (locally and globally) and status (current land tenure, level of protection, threats to their integrity); 
- development of a strategy to ensure that the values of cloud forests are recognized and fully considered in decision-making processes;

- implementation of management regimes that take account of the legitimate demands of local people for access to and usage of forest products in a sustainable way.

Acknowledgments. The authors thank their colleagues in Gland and around the world who provided valuable information and helpful comments on the drafts.

\section{References}

Bruijnzeel, L. A. 1990. Hydrology of moist tropical forests and effects of conversion: A state of knowledge review. Paris: Unesco.

Colinvaux, P. A. 1989. The past and future Amazon. Scientific American 68-74.

Costin, A. B., and D. J. Wimbush. 1961. Studies in catchment hydrology in the Australian Alps. 4) Interception by trees of rain, cloud and fog. CSIRO Australian Division of Plant Industry Technical Paper 16, Canberra, Australia.

Cusset, G. 1989. La flore et la végétation du Mayombe congolais. Etat des connaissances. In Revue des connaissances sur la Mayombe, ed. J. Sénéchal, Matuka Kabala, and F. Fournier, 103-136. Paris: Unesco.

Dasmann, R. F., and D. Poore. 1979. Ecological guidelines for balanced land use, conservation and development in high mountains. UNEP, Nairobi, IUCN, and WWF, Gland, Switzerland.

Doumenge, C., and Y. Renard. 1989. La conservation des écosystèmes forestiers de l'île de la Réunion. Gland, Suisse et Cambridge, Royaume-Uni: IUCN.

Dowsett-Lemaire, F. 1991. The vegetation of the Kouilou bassin in Congo. In Flore et faune du bassin du Kouilou (Congo) et leur exploitation, ed. R.J. Dowsett and F. Dowsett-Lemaire. Tauraco Research Report 4:17-51.

FAO. 1992. Aménagement et conservation des forêts denses en Amérique tropicale. FAO, Etude Forêts 101, Rome.

FAO. 1993. Summary of the final report of forest resources assessment 1990 for the tropical world. Paper prepared for the 11 th COFO meeting, Rome.

Hamilton, A. C., and R. Bensted-Smith, eds. 1989. Forest conservation in the East Usambara Mountains, Tanzania. Gland, Switzerland, and Cambridge, UK: IUCN.

Jacobs, M. 1988. The tropical rain forest: A first encounter. Berlin and Heidelberg, Germany: Springer-Verlag.

Kerfoot, O. 1968. Mist precipitation on vegetation. Forestry Abstracts 29:8-20.

LaBastille, A., and D. J. Pool. 1978. On the need for a system of cloud-forest parks in Middle America and the Caribbean. Environmental Conservation 5(3): 183-190.

Letouzey, R. 1985. Notice de la carte phytogéographique du Cameroun au 1:500 000 (1985). 2) M-SM: Région afro-montagnarde et étage submontagnard. Toulouse, France: Institut de la Carte Internationale de la Végétation.

Luteyn, J. L. 1989. Speciation and diversity of Ericaceae in Neotropical montane vegetation. In Tropical forests. Botanical dynamics, speciation and diversity, ed. L.B. Holm-Nielsen, I.C. Nielsen, and H. Balslev, 297-310. London: Academic Press.

Madduma Bandara, C. M., and T. A. Kurupuarachchi. 1988. Land-use change and hydrological trends in the upper Mahaweli basin. For workshop on hydrology of natural and man-made forests in the hill country of Sri Lanka, Kandy. Unpublished.

Morlon, P., ed. 1992. Comprendre l'agriculture paysanne dans les Andes Centrales. Paris: INRA. 
Nadkarni, N. M. 1988. Tropical rain forest ecology from a canopy perspective. In Tropical rainforests: Diversity and conservation, ed. F. Almeda and C.M. Pringle, 189-208. San Francisco: California Academy of Sciences and American Association for the Advancement of Science.

Persson, R. 1974. World forest resources. Stockholm: Royal College of Forestry.

Poore, D. 1992. Guidelines for mountain protected areas. Gland, Switzerland, and Cambridge, UK: IUCN Commission on National Parks and Protected Areas.

Sayer, J. A., C. S. Harcourt, and N. M. Collins, eds. 1992. The conservation atlas of tropical forests. Africa. Gland, Switzerland, and Cambridge, UK: IUCN.

Sosa, V. J. 1987. Generalidades de la región de Gómez Farías. In El bosque mesofilo de montaña de Tamaulipas, ed. H. Puig y R. Brach, 15-28. México: Instituto de Ecología.

Stadtmuller, T. 1987. Cloud forests in the humid tropics. A bibliographic review. United Nations University, Tokyo, and CATIE, Turrialba, Costa Rica.

Stuart, S. N., R. J. Adams, and M. D. Jenkins. 1990. Biodiversity in Sub-Saharan Africa and its islands. Conservation, management and sustainable use. IUCN, Occasional Papers of the IUCN Species Survival Commission 6, Gland, Switzerland.

Thomas, D. W., and G. Achoundong 1991. Montane forests of Western Africa. In AETFAT Congress.

Torres, H., R. Borel, N. Bustamante, and M. I. Centeno. 1992. Usos tradicionales de arbustos nativos en el sur de Puno. Puno, Perú: Intercooperation.

Unesco. 1981. Vegetation map of South America. Explanatory notes. Paris: Unesco.

Vogelmann, H. W. 1973. Fog precipitation in the cloud forests of Eastern Mexico. BioScience 23(2): 96-100.

White, F. 1983. The vegetation of Africa. Paris: Unesco.

Whitmore, T. C. 1975. Tropical rain forests of the Far East. London: Oxford University Press. 
Lawrence S. Hamilton

James O. Juvik

F. N. Scatena

Editors

\section{Tropical Montane \\ Cloud Forests}

With 102 illustrations
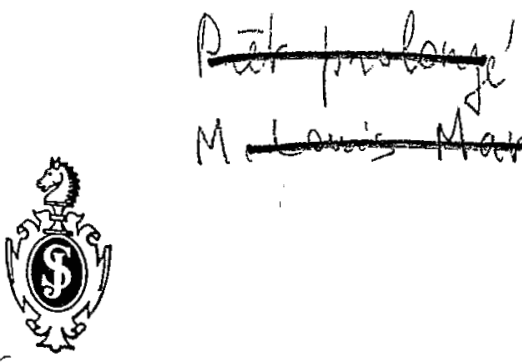

Springer-Verlag

New York Berlin Heidelberg London Paris

Tokyo Hong Kong Barcelona Budapest Fond's DocLmentaire Ofs

I5 MAl 1995 Cote: $\beta * 6196$ Ex:

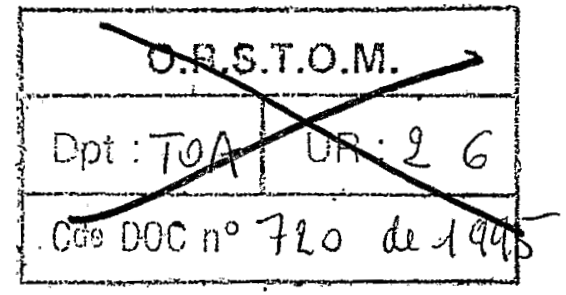

